\title{
The Response of Benthic Foraminiferal Assemblages to Copper Exposure: A Pilot Mesocosm Investigation
}

\section{Frontalini Fabrizio, Coccioni Rodolfo}

Dipartimento di Scienze della Terra, della Vita e dell'Ambiente (DiSTeVA), Università degli Studi di Urbino “Carlo Bo", Urbino, Italy.

Email: fabrizio.frontalini@uniurb.it

Received February $4^{\text {th }}, 2012$; revised February $28^{\text {th }}, 2012$; accepted March $29^{\text {th }}, 2012$

\begin{abstract}
Controlled experiments, including mesocosms and laboratory cultures, are used to identify a potential specific causeeffect relationship that has been previously inferred in field studies. In this study, a series of mesocosm experiments are carried out to assess the impact of different concentrations of copper on benthic foraminiferal assemblages over time. This pilot investigation documents that $\mathrm{Cu}$ contamination has a detrimental effect on foraminifera when compared to original and control samples. In particular, increased concentrations of $\mathrm{Cu}$ (normally higher than $120 \mu \mathrm{g} / \mathrm{l}$ ) lead to a lowering of foraminiferal density and diversity and an increased occurrence of abnormalities. This study thus supports that the use of an experimental approach is suitable for investigating the response of benthic foraminifera to stress including pollution. Moreover, the application of mesocosms represents an innovative tool to be placed alongside field studies and culture experiments.
\end{abstract}

Keywords: Mesocosm; Benthic Foraminifera; Copper; Pollution

\section{Introduction}

Marine environments, particularly estuaries and shallow near-shore areas, are increasingly subject to anthropogenic impact and are recipients of various kinds of anthropogenic waste. The governments of many countries have applied and continue to develop marine and ecosystem protection policies covering coastal-marine and transitional ecosystems. The definition and implementation of these policies require the provision of reliable and comparable data and information, as well as suitable assessment and monitoring tools.

In this context, foraminifera are presently one of the best known and most comprehensively studied of the microfossils, and are among the most abundant protozoa in the marine realm. Benthic foraminifera are marine unicellular organisms protected by a calcareous, agglutinated or organic external shell. Because of their widespread distribution, short life and reproductive cycles, high biodiversity, and specific ecological requirements, foraminifera respond to environmental changes [1]. They are commonly small and abundant compared to other hard-shelled taxa (such as mollusks, which are often used for pollution monitoring) and are also easy to collect, providing a highly reliable database for statistical analysis, even when only small sample volumes are available.
They are also particularly sensitive, and it has been convincingly demonstrated that the study of their assemblages is a reliable tool with which to assess the environmental impact of pollutants in a wide range of marine environments [2-7]. Benthic foraminifera have been successfully used as proxies for studying the impact of a number of pollutants, including "heavy" metals, chemicals and oil, as well as thermal and organic (pulp mill, aquaculture and sewage) contaminants [2, for a review]. Moreover, they generally respond to adverse ecological conditions by primarily undergoing: 1) local extinctions; 2) compositional biocoenosis changes; 3) assemblage modifications, which include changes in abundance, diversity and test size; and 4) the development of test abnormalities $[3,7,8]$. Despite the fact that major advances in our capacity to decipher benthic foraminiferal ecology have been made over the last 50 - 60 years [7,9], for reviews, we are still far from fully understanding the dynamics thereof in polluted environments. Indeed, field surveys of foraminiferal assemblages do not always directly allow the identification of the mechanisms underlying ecological responses to pollution. Furthermore, the most severely polluted areas are often naturally stressed, and this makes it difficult to interpret what proportion of observed local variations in assemblage composition and parameters are due to natural or anthropogenically in- 
duced changes $[5,6]$. The complex scenario, where natural vs. human induced stress occurs contemporarily, is further complicated by the occurrence of different kinds of pollutants and their synergic and antagonistic interrelation. Under these circumstances, assessing the role played by a single factor is undoubtedly difficult, while the influence of additional factors on benthic foraminiferal assemblages can also not be ruled out. Experimental approaches can, however, provide insight into key impact mechanisms by examining each potential variable in isolation. Accordingly, laboratory experiments, through which benthic foraminiferal responses to various types and concentrations of pollutants can be observed over time, represent the most effective and direct way of evaluating and assessing the effect of a single parameter. In particular, such experiments enable continuous and accurate observations to be made of the benthic foraminiferal response under controlled conditions. In these circumstances, a single parameter can be altered, with the rest remaining constant, in order to note the response to a variation in a particular parameter. In this way, the benthic foraminiferal reaction to specific parameters can be directly characterized, adding credibility to and validating field based observations. Some laboratory experiments have been conducted by simulating stress conditions (e.g. variations in $\mathrm{pH}, \mathrm{pCO}_{2}$, temperature, food type and salinity, organic matter, $\mathrm{Cu}, \mathrm{Hg}$ and oil) using a series of monospecific cultures (e.g. Ammonia aomoriensis, Ammonia beccarii, Ammonia tepida, Haynesina germanica, Pararotalia nipponica, Bulimina marginata and Rosalina leei), for a review see [10]. Furthermore, along with field studies, these experiments can be integrated with mesocosm tests that effectively represent the natural conditions (i.e. in the original sediment) where foraminifera live. A very limited number of mesocosm experiments have previously been conducted [11-19]. In colonization research, [20] evidenced minor changes in benthic foraminiferal assemblages exposed to high concentrations of $\mathrm{Cu}$ in sediments. These changes included an increase in equitability, a reduced abundance and negative effects on Stainforthia fusiformis and Bolivinella pseudopuctata. A lowering in foraminiferal abundance when exposed to tributyltin was documented [12]. It has also been revealed that secondary treated sewage-derived particulate organic matter does not have a direct effect on the food source of the foraminifera or their diet [19]. Furthermore, in a laboratory study of the impact of oil on intertidal faunas, [18] revealed that the toxicity of oil components may lead to increased mortality in foraminiferal faunas, particularly in some species which react with reproductive events, leading to a sudden increase in their density and a strong increase in their relative abundance.

The available results from studies carried out in both the field and the laboratory have demonstrated the effectiveness of benthic foraminifera as a pollution proxy in marine ecosystems. However, a more concrete understanding of the various disturbing processes, as well as the biological response mechanisms related to pollution, can be achieved by using mesocosms. Moreover, a better understanding of the quantitative and temporal relationships between environmental forcing (concentrations of single pollutant) and benthic foraminiferal responses will enable us to improve reliability and efficiency when using these foraminifera as a proxy for environmental pollution in marine ecosystems. It will also mean that decision-makers and governmental bodies will be able to use these micro-organisms in environmental monitoring and the management of marine ecosystems.

The main aim of this research was to test the feasibility of the pilot mesocosm experiments and document the response of benthic foraminifera in terms of parameter changes to various concentrations of $\mathrm{Cu}$ over time under laboratory controlled conditions. In order to achieve these goals, 28 mesocosm experiments were monitored for a period of two months.

\section{Copper and Pollution}

Copper, as with others trace elements, plays a biologically essential role in the growth and life of most aquatic organisms. Above a specific threshold, however, it may potentially become toxic to marine and estuarine organisms [21]. Copper is a common contaminant with a high toxicity when it comes to marine organisms in coastal areas, particularly in industrialized bays, lagoons and estuaries. Inputs of copper into natural water come from different sources, including mining, smelting, domestic and industrial activities and from algaecides and anti-fouling paint on boat hulls. High levels of $\mathrm{Cu}$ in the sediment are considered to be toxic for aquatic animals, including meio- and macrofauna [22]. Copper ions can form complexes with organic materials, as well as bind to particles of sediment, and much of the copper entering the coastal environment is therefore become incorporated into sediment [23]. It is thus of paramount importance determining its bioavailability, which essentially depends on a suite of physical, chemical and biological factors in the sediment. The Sediment Quality Guidelines (SGQ) of the U.S. Environmental Protection Agency (USEPA) introduced the "Effects Range-Low" (ERL) value, which represents the concentrations below which adverse effects rarely occur, and the "Effects Range-Median" (ERM) value, which represents the concentrations above which such effects frequently occur [24]. For $\mathrm{Cu}$, the ERL and ERM have been set at 34 and 270 ppm, respectively. 


\section{Material and Methods}

\subsection{Collection Site and Sampling}

On May 18, 2009, sediment and seawater were collected in front of Fano, which is in the northern part of the Marche region (central Adriatic Sea, Italy). The collection site is located at a water depth of $14.5 \mathrm{~m}$, and is a coastal zone characterized by oligo-mesotrophic conditions and particularly low levels of human activity. This site was selected because it is clean and because previous studies $[25,26]$ have documented a well-diversified foraminiferal assemblage there. Then, using a multi-parametric probe, the temperature, $\mathrm{pH}$, salinity, Eh and dissolved oxygen (DO expressed as $\mathrm{mg} / \mathrm{l}$ ) content of the seawater were measured in a vertical profile.

Sediment was collected by deployment a Van Veen grab several times to ensure that sufficient material was gathered, which is a technique that has been previously used by [15] and [17]. Once on board, the grab was carefully opened and a large amount of surficial sample $(\sim 0-2 \mathrm{~cm})$ was collected. The surficial material was used since most foraminifera live in this part of the sediment. It was then stored in one large box and kept at $20^{\circ} \mathrm{C}$ (average ambient temperature of bottom waters during May, [26]). The box was filled with ambient seawater and aerated several times during transport to the laboratory by removing the cap and stirring the water column gently. Seawater was collected near to the sediment-water interface at the same site. Three random replicated sub-samplings of the sediment were retrieved from the original sample, homogenized and used for foraminiferal, grain-size and geochemical analyses following the procedures described below. These preliminary analyses enabled us to evaluate the sediment characteristics and determine species' abundances before the start of the experiment.

\subsection{Laboratory Treatment}

Following [15], the sediment was homogenized upon arrival in the laboratory and sieved with ambient seawater over the $710 \mu \mathrm{m}$ screen to remove macrofauna and meiofauna taxa in order to eliminate the potentially disturbing effects of bioturbators and the few larger predators. We used the ambient seawater during the sieving treatment. The aim of the homogenization process was to minimize the effect of foraminiferal patchiness in the sample and to create identical starting conditions for mesocosms, ideally containing the same number of living fauna and having similar geochemical conditions. This also eliminated the factor of the variable grain size of the sediments, which might have affected the comparability of the samples [19]. The seawater was then left to stabilize for salinity and $\mathrm{pH}$ values that were similar to those at the time of collection.

\subsection{Original Sediment Characterization}

The homogenized three-replicated sediment samples were split into four aliquots for different analyses. The first, which was used for grain-size analysis, was treated with an $\mathrm{H}_{2} \mathrm{O}_{2}$ solution, sieved on a $63 \mu \mathrm{m}$ screen to separate the fine fraction (mud) and dried at $40^{\circ} \mathrm{C}$. The grain size analysis was carried out to determine the percentage of mud, while the sand fraction was established by means of a series of ASTM sieves.

The second aliquot was dried, reduced to a fine powder and used to determine trace element content in the sediment samples. Activation Laboratories Ltd. [27] analyzed a fraction of $0.5 \mathrm{~g}$ samples for 56 elements using Inductively Coupled Plasma Mass Spectrometry (ICPMS), which is a multi-element technique capable of measuring concentrations at very low detection limits $\left(\mathrm{mg} \cdot \mathrm{kg}^{-1}\right.$ to $\mu \mathrm{g} \cdot \mathrm{kg}^{-1}$ ). The sample was digested with four acids beginning with hydrofluoric, followed by a mixture of nitric and perchloric acids. It was then heated using precise programmer controlled heating in several ramping and holding cycles, which dries the samples. After dryness was attained, the samples were returned to a solution using hydrochloric and nitric acids. It should be noted that this digestion may not be complete if resistate minerals are present. Moreover, $\mathrm{As}, \mathrm{Sb}$ and $\mathrm{Cr}$ may be partially volatilized. The digested sample was diluted and analyzed by a Perkin Elmer Sciex ELAN 6000, 6100 or $9000 \mathrm{ICP} / \mathrm{MS}$. One blank was run for every 40 samples, an in-house control every 20 samples and the digested standards every 80 samples. After every 15 samples, a digestion duplicate was analyzed. The instrument was recalibrated every 80 samples. A further aliquot of a sample $(\sim 0.5 \mathrm{~g})$ was digested with aqua regia at $90^{\circ} \mathrm{C}$, and the $\mathrm{Hg}$ in the resulting solution was oxidized to the stable divalent form. Since the concentration of $\mathrm{Hg}$ was determined via the absorption of light at $253.7 \mathrm{~nm}$ by $\mathrm{Hg}$ vapor, $\mathrm{Hg}$ (II) was reduced to the volatile free atomic state using stannous chloride. Argon was bubbled through the mixture of sample and reductant solutions to liberate and transport the $\mathrm{Hg}$ atoms into an absorption cell. The cell was placed in the light path of an Atomic Absorption Spectrophotometer. The maximum amount absorbed (peak height) was directly proportional to the concentration of mercury atoms in the light path. Measurements were carried out automatically using a flow injection technique (FIMS). The $\mathrm{Hg}$ analysis was performed on a Perkin Elmer FIMS 100 cold vapor Hg analyzer.

The third aliquot was used for documenting the benthic foraminiferal assemblages at the time of sample collection, and the procedure used is described in Section 
3.7.

\subsection{Preparation of the Copper-Water Mixture and Experimental Setup}

In order to study the effect of $\mathrm{Cu}$ on benthic foraminiferal assemblages, seawater mixtures with contaminants at different concentrations were prepared. Pollutant concentrations for experimental media were obtained by adding appropriate volumes of stock solutions to seawater. The level of exposure was selected to be realistic compared to "natural" environments. In particular, six different concentrations $(60 \mu \mathrm{g} / \mathrm{l}, 120 \mu \mathrm{g} / \mathrm{l}, 240 \mu \mathrm{g} / \mathrm{l}, 480$ $\mu \mathrm{g} / \mathrm{l}, 1200 \mu \mathrm{g} / \mathrm{l}, 2400 \mu \mathrm{g} / \mathrm{l})$ of copper solutions were prepared by dissolving water soluble copper chloride $\left(\mathrm{CuCl}_{2}\right)$ in seawater. Four mesocosms without contaminants were run and served as controls.

\subsection{Mesocosms}

After laboratory treatment and settlement for one day, the sediments were deposited in 28 mesocosms (24 treatments and four controls) for a period of two months. The experimental periods were long enough to monitor the response of the benthic foraminiferal assemblages in terms of parameter assemblages. Following [18], incubating $\sim 7 \mathrm{~cm}$ of sediment would have resulted in high densities of living foraminifera near the sediment-water interface. Almost the same amount of sediment was used for all mesocosms and filled with six different copperwater mixture concentrations. Four mesocosms without copper were run and served as controls. In these mesocosms, which were maintained without any supply of nutrients, half of the volume of the water was renewed every week with seawater from the collecting site, while the salinity was kept stable. The seawater had a salinity of ca. 36\% - 38\% which, following [25], would have been the normal salinity reported for the area at the time of collection. The salinity was kept constant by frequently changing the seawater. The mesocosms were not kept under ambient hydrostatic pressure, since previous studies [28] have suggested that there was no need to do so with material collected from these, relatively, shallow depths.

\subsection{Sub-Samples of Mesocosms and Time Experimental Setup}

The sampling of the experimental mesocosms involved a number of steps, which were followed during all sampling phases of the experiment. A constant volume $(\sim 50$ $\mathrm{cm}^{3}$ ) from any mesocosm at different contaminant concentrations was taken from the upper $\sim 1-2 \mathrm{~cm}$ of each sample. All of the sub-samples were labeled with the nominative concentrations and the time of sampling (one week, two weeks, four weeks, and eight weeks).

\subsection{Taxonomic and Quantitative Analysis of the Foraminiferal Assemblages}

Following the method described by [29], the sediment was stained with buffered rose Bengal dye ( $2 \mathrm{~g}$ of rose Bengal in $1000 \mathrm{ml}$ of ethyl alcohol) immediately after sampling for at least $48 \mathrm{~h}$ to distinguish living foraminifera. According [30], only specimens containing dense, brightly red-stained protoplasm were counted as alive. The samples were sieved over $63 \mu \mathrm{m}$ mesh-size screens, dried at $50^{\circ} \mathrm{C}$ and weighed. They were then gently washed through a $63 \mu \mathrm{m}$ sieve with tap water to remove clay, silt and any excess dye. The residual fractions so obtained were re-dried at $50^{\circ} \mathrm{C}$ and weighted to determine by their difference the mud fraction. Quantitative analyses of the benthic foraminifera were performed on the fraction $>90 \mu \mathrm{m}$. The living (stained) foraminifera were hand-picked and separated from the sediment for faunal analysis. All live (stained) benthic foraminifera were picked, identified and counted. They were then taxonomically identified at genus level, largely following $[25,31,32]$. Then, mainly following [25] and [33], several parameters linked to the assemblages were calculated, including foraminiferal density (FD), species richness (S), the Foraminiferal Abnormality Index (FAI, defined as the percentage of abnormal specimens within the sample) and $\mathrm{n} / \mathrm{N}$ (defined as the percentage of specimens $<125$ $\mu \mathrm{m}$ within the assemblages).

\section{Material and Methods}

\subsection{Field Distribution}

\subsubsection{Sediment Chemistry and Grain-Size}

The sediments are primarily composed of mud ( $69 \%)$. Trace element concentrations are compared to the ERL (Effect Range Low) and ERM (Effect Range Median) values contained in the sediment guidelines produced by the U.S. Environmental Protection Agency (USEPA) [24]. All of these elements have a concentration that is lower than the ERL, although $\mathrm{Ni}$ has a value that is greater than the ERM. The copper concentration at the beginning of the experiment is $32.1 \mathrm{ppm}$, which is slightly lower than the ERL (34 ppm). These trace element concentrations can be compared to those reported by [25] along the central-northern part of the Marche region.

\subsubsection{Composition of the Original Foraminiferal Assemblages}

The studied sample contains abundant and well preserved living benthic foraminifera. The assemblages are mainly represented by hyaline species $(\sim 91 \%)$, with minor percentages of porcelanaceous and agglutinated foraminifera. 
The biocoenosis is dominated by Ammonia ( 71\%) and subordinately by the Elphidium, Aubignyna, Haynesina, Bolivina and Bulimina genera. Accessory genera include Hopkinsina, Eggerelloides, Haynesina and Buliminella. This living assemblage is largely dominated by infaunal genera. Epifaunal taxa, which mainly belong to Quinqueloculina and the keeled Elphidium genera, are present in low abundance. The biocoenosis is characteristic of shallow, oligotrophic and moderately oxygenized environments, and is typical of the area investigated by [25, 26]. Most of the biocoenosis is constituted of herbivore feeding forms with a marked preference for mud and/or fine sand substrates. The genus Ammonia from the studied area chiefly consist of A. parkinsoniana and, albeit subordinated, the opportunistic species, A. tepida. Representatives of this genus dominate shallow water environments all over the world. In particular, A. parkinsoniana, which is typical of relatively clean environments [34], is very common all along the Italian coast between a water depth of 10 and $20 \mathrm{~m}$, irrespective of the substratum type and percentage of organic matter [35]. On the other hand, A. tepida, which represents only a minor fraction of the assemblage, is known for its great tolerance to all kinds of stressful conditions $[5,6]$. The FD and S have values of 43.8 and 29 , respectively. Higher values of FD and S are found when compared to those provided by [6]. These higher values probably reflect a slightly deeper water depth. The low percentage of the FAI $(0.54)$ is the typical value recognized in unpolluted sites in this area [6] and can be compared with similar values reported in a non-stressed population. Indeed, [36] observed about $1 \%$ of abnormal tests in laboratory cultures of Ammonia under normal conditions, whereas [37] found $1.75 \%$ of abnormal tests in a monospecific culture of A. tepida living in an unpolluted microcosm with $35 \%$ salinity. The percentages of specimens $<125 \mu \mathrm{m} \mathrm{n} / \mathrm{N}$ is 20.5 .

\subsection{Copper-Treated Mesocosms and Benthic Foraminifera}

All of the samples, at any concentrations and times, contain abundant and well preserved living benthic foraminifera. The assemblages' taxonomic composition is similar to that recognized in the original assemblages, and treatment seems to have had a limited effect (Figures 1-4). The FD documented in all of the mesocosms is lower than that calculated in the original composition, and it is probable that all of the initial treatments may have slightly affected the assemblages to some extent. The FD ranges from 12.3 (2400/W8) to 31 (0/W1). Although a clear reduction trend of FD can be observed with time exposure, and even within the control experiment, it is more pronounced as the concentrations rise
(Figure 1). After one week (W1), all of the mesocosms exhibit similar FD values, whereas in the following weeks (W2, W4, and W8) a lowering in FD can be observed and become more evident at concentrations higher than $120 \mu \mathrm{g} / \mathrm{l}$. No particular difference in FD between the control and the concentration of $60 \mu \mathrm{g} / \mathrm{l}$ is observed (Figure 1). The decreasing FD values can be explained in terms of higher mortality (or a lowering in reproduction) in response to the presence of a contaminant. However, the reduction in FD is also evident in the control experiment over time, and may be due to a reduction of food availability within the sediment, or to the presence of potential small predators that were not excluded through sieving (e.g. ostracods). A lowering in FD in response to trace element pollution has been widely reported in both field and mesocosm studies [20,38]. In particular, increased equitability and reduced abundances have been documented in sediment with very high $\mathrm{Cu}$-concentrations (>900 ppm), whereas lower concentrations appear to not significantly affect the FD [20]. The same results were achieved by [18], who documented a lowering in FD in all mesocosms exposed to oil pollution, including the control. In all of the oil-treated mesocosms, however, the FD reduction in the $>150 \mu \mathrm{m}$, as well the $63-150 \mu \mathrm{m}$, fractions was enhanced when compared to the control. An increase in foraminiferal mortality and a possible inhibition of foraminiferal reproduction were suggested. A similar decrease in FD in response to $2.00 \mathrm{nmol} / \mathrm{g}$ TBT exposition for seven months was reported by [12]. However, this decrease is within the confidence limit when compared to the control. An unclear trend was evidenced in the $\mathrm{n} / \mathrm{N}$, which ranged from $17.7(1200 / \mathrm{W} 1)$ to $33.3(2400 / \mathrm{W} 2)$, with a mean value of 24.4 (Figure 2). The values after one week (W1) reveal a similar value in the original assemblages, especially for the control and the $60-240 \mu \mathrm{g} / \mathrm{l}$ mesocosms. An overall increase of $n / N$ is shown over time, and generally higher values are associated with increased $\mathrm{Cu}$ concentrations. The $\mathrm{S}$ ranges between 12 and 25, with a mean of 19 (Figure 3). Higher diversity values are recognized in the two weeks (W1 and W2) after the beginning of the experiment and at low $\mathrm{Cu}$-enrichment $(<120$ $\mu \mathrm{g} / \mathrm{l}$ ) in the following weeks (W4 and W8). Although no significant correlation between $\mathrm{S}$ and $\mathrm{Cu}$ concentrations is found in our research, decreasing values in both control samples and those treated with increasing levels of $\mathrm{Cu}$ have been documented by [20]. The FAI varied from 0.58 to 2.87 , with a mean value of 1.56 (Figure 4). These values are within the range of variability for this area. Indeed, [25] have previously documented mean FAI values between 1.4 and 2.5 for unpolluted and very slightly polluted areas, respectively.

Several kinds of abnormality are recognized: 1) reduced chamber (s) size; 2) aberrant chamber shape; 3) distorted 

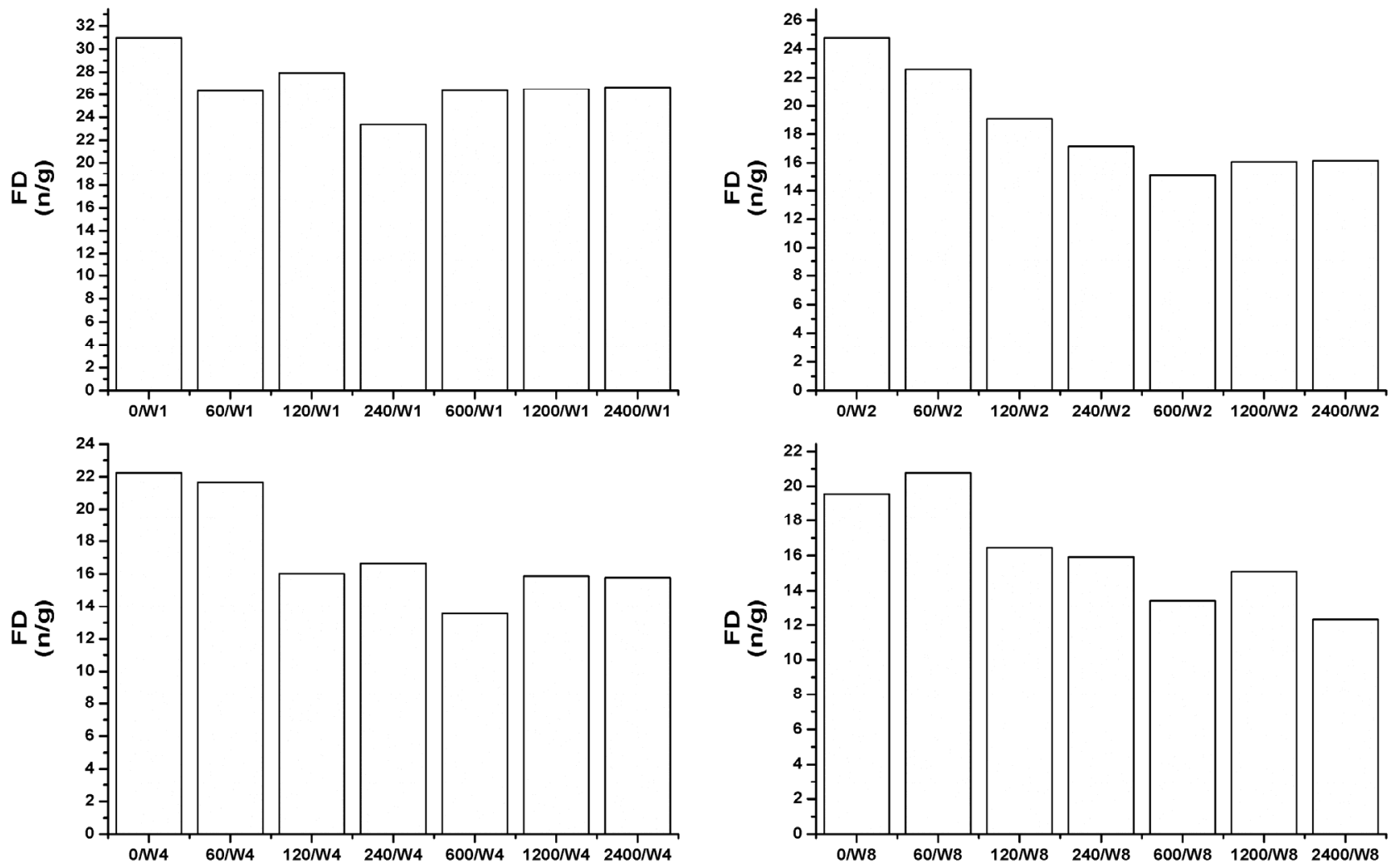

Figure 1. Foraminiferal density (FD) in control and Cu-treated mesocosms over the duration of the experiment.
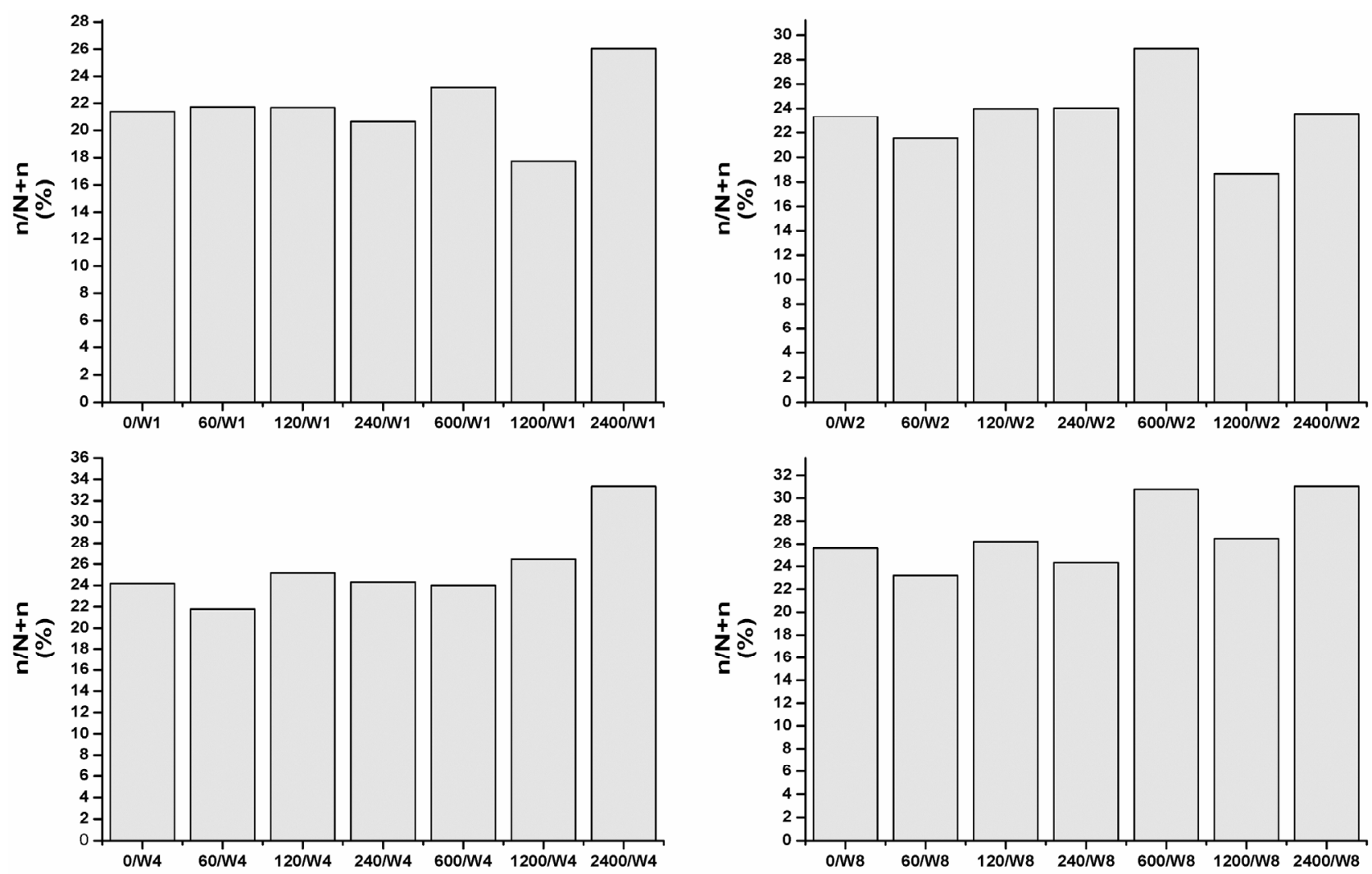

Figure 2. Percentages of specimens $<125 \mu \mathrm{m}(\mathrm{n} / \mathrm{N})$ in control and Cu-treated mesocosms over the duration of the experiment. 

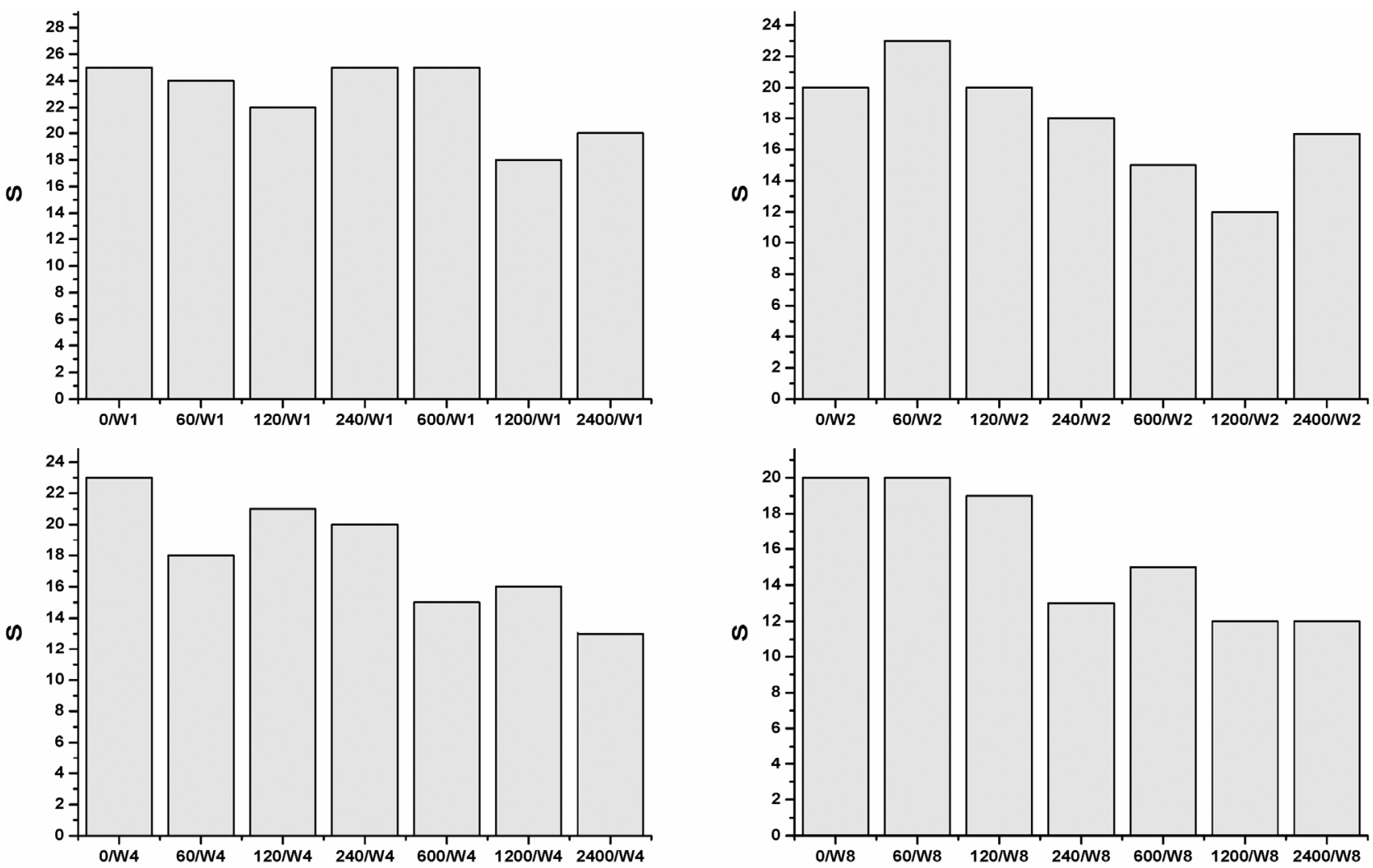

Figure 3. Species richness (S) in control and $\mathrm{Cu}$-treated mesocosms for the duration of the experiment.
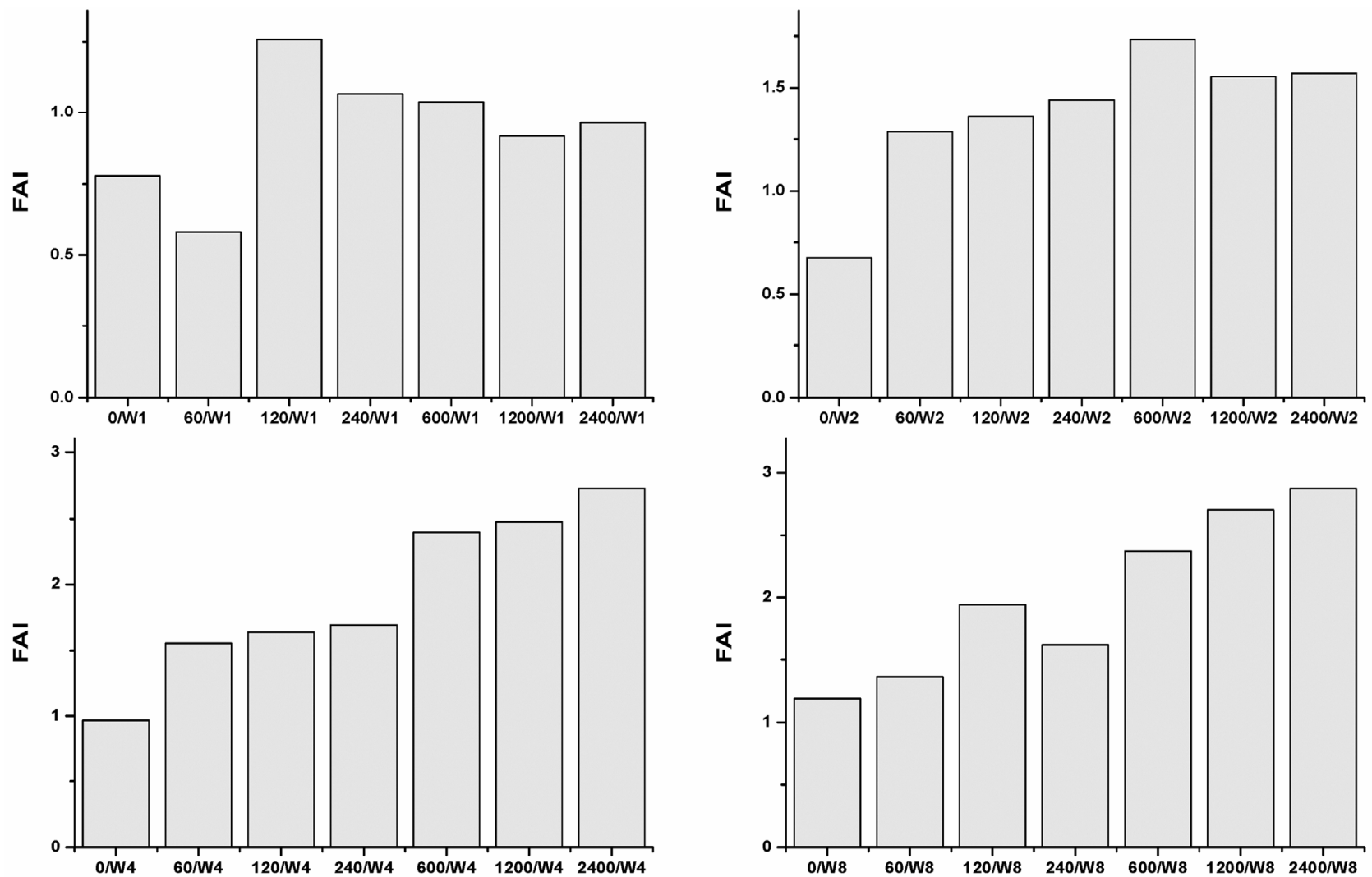

Figure 4. Foraminiferal abnormality index (FAI) in control and Cu-treated mesocosms over the duration of the experiment. 
chamber arrangement or change in coiling; 4) abnormal additional chamber(s); 5) abnormally protruding chamber (s); 6) Siamese twins; and 7) non-developed tests (Plate 1). The occurrence of abnormal specimens is not restricted to $\mathrm{Cu}$-treated mesocosms, but can also be observed in the control mesocosms. Increasing values of the FAI are also observed both over time and concentrations. Moreover, several relatively small tests of Ammonia with a large proloculus, namely the so-called megalospheric forms, are noted after eight weeks. These specimens were not restricted to $\mathrm{Cu}$-enriched mesocosms. Indeed, [39] have previously found that megalospheric forms of A. tepida were dominant at stations where this toxic trace metal was prevalent. [40], meanwhile, suggested that foraminifera under stressed conditions, including changes in salinity, nutrients and oxygen depletion, might change to an asexual mode of reproduction.

Field and experimental data provide evidence of $\mathrm{Cu}$ toxicity in benthic foraminifera after expositions. In particular, the benthic foraminiferal colonization in $\mathrm{Cu}-$ contaminated sediments was investigated by [20]. Their study provides compelling evidence that high ( $\sim 970 \mathrm{ppm})$ to very high $(\sim 1760-2400 \mathrm{ppm})$ concentrations of copper in sediment have a detrimental effect on benthic foraminiferal assemblages, including reduced abundance and diversity and increased equitability. However, no relation between the occurrence of abnormal specimens and $\mathrm{Cu}$ contamination was found. The response of two species of Ammonia cultured at different concentrations of $\mathrm{Cu}$ was investigated by [41], who documented a negative effect at concentrations as low as $10 \mu \mathrm{g} / \mathrm{l}$ and a lethal value at $200 \mu \mathrm{g} / \mathrm{l}$. The increased pollution led to delays in the construction of new chambers and reproduction, which the authors linked to the possible low density recognized in the polluted area. They also found increased values of abnormality and some cytological modifications in abnormal specimens. Furthermore, according to [42], concentrations of $10-20 \mu \mathrm{g} / \mathrm{l}$ might induce the development of abnormalities in the species $A$. beccarii. Meanwhile, [43] investigated the effects of $\mathrm{Cu}, \mathrm{Mn}$ and $\mathrm{Ni}$ incorporation in the foraminiferal calcite of A. tepida under laboratory controlled conditions. Although the concentrations of $\mathrm{Cu}(295 \mathrm{nmol} / \mathrm{l}$ to $3290 \mathrm{nmol} / 1$ that equal 14 and $210 \mu \mathrm{g} / \mathrm{l})$ used in their experiment were comparable to those used by [41], only a lowering in the number of added chambers was documented. However, according to [43], an antagonistic effect among $\mathrm{Cu}$ and other elements (e.g. Mn) cannot be ruled out. In culturing experiments on A. tepida and Heterostegina depressa, [44] pointed out that even high concentrations of $\mathrm{Cu}$ do not cause test abnormalities, but $H$. depressa does not survive in these circumstances $(20 \mu \mathrm{mol} / \mathrm{l})$. The development of abnormal tests on A. tepida exposed to $5.5 \mathrm{mg}$ of oil in $100 \mathrm{ml}$ of seawater has also been reported in

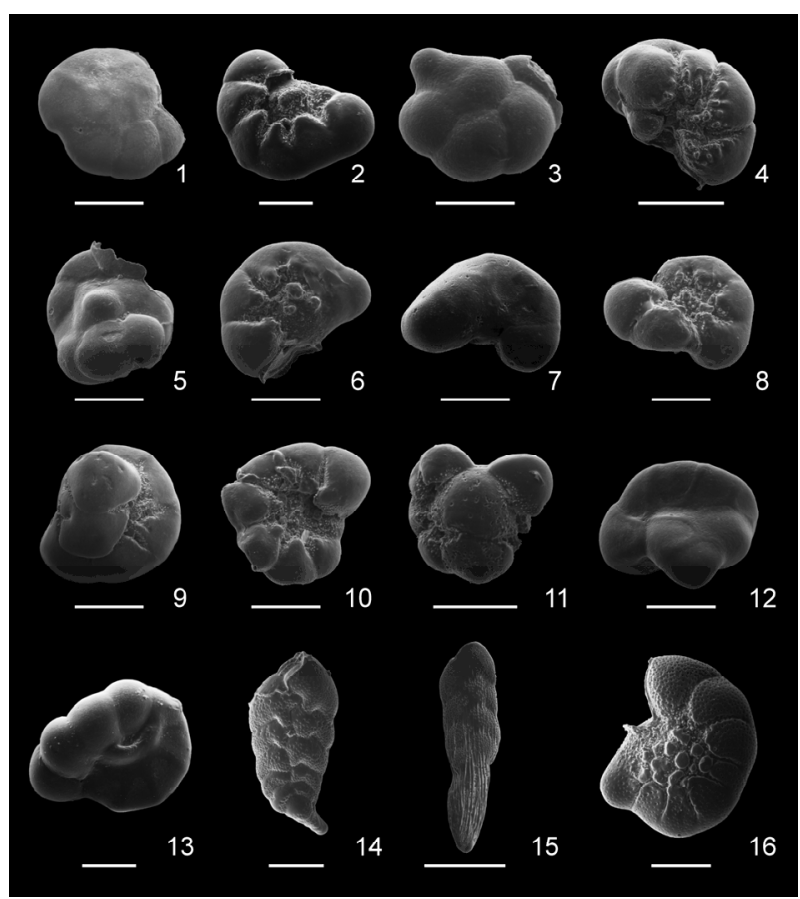

Plate 1. SEM photomicrographs showing examples of morphological abnormalities in benthic foraminifera. 1-2) Ammonia parkinsoniana (d'Orbigny), undeveloped tests; 3) Ammonia tepida Cushman, reduced chamber(s) size; 4) Ammonia sp., distorted chamber arrangement or change in coiling; 5) Ammonia tepida Cushman, megalospheric form with distorted chamber arrangement or change in coiling; 6-7) Ammonia parkinsoniana (d'Orbigny), undeveloped tests; 8) Ammonia tepida Cushman, distorted chamber arrangement or change in coiling; 9) Ammonia parkinsoniana (d'Orbigny), umbilical view shows protuberances in the form of bulla-like chamber covering the umbilicus; 10) Ammonia sp., aberrant chamber shape; 11) Ammonia tepida Cushman, Siamese twins; 12-13) Ammonia parkinsoniana (d'Orbigny), distorted chamber arrangement or change in coiling; 14) Bolivina sp., distorted chamber arrangement; 15) Bolivina striatula (Cushman), reduced chamber sizes; 16) Elphidium lidoense (Cushman), abnormally protruding chamber. Scale bar $=100 \mu \mathrm{m}$.

petri-dish experiments by [37]. The development of abnormal specimens, as well as a reduction in foraminiferal size, has likewise been documented in R. leii exposed to $\mathrm{Hg}$ [45]. These results were confirmed by [46], who evidenced a more acute effect on $R$. leii when the addition of $\mathrm{Hg}$ was sudden rather than gradual. The response to As of Amphistegina gibbosa, a common Caribbean reef foraminifera, was evaluated by [47], who demonstrated a suppression of growth at concentrations greater than 50 $\mu \mathrm{g} / \mathrm{kg}$ and $100 \mu \mathrm{g} / \mathrm{kg}$ for $\mathrm{As}^{3+}$ and $\mathrm{As}^{5+}$, respectively. A decrease in the density and diversity of meiofaunal assemblages exposed to copper contamination was documented at concentrations of 50 to $150 \mu \mathrm{g} / \mathrm{l}$ through microcosm experiments [48]. These decreases were statistically significant for foraminifera, harpacticoid cope- 
pods and polychaetes. On the other hand, there were no statistically significant reductions in the density of ostracods and nematodes, while no reductions at all of turbellarians, halacarids and tardigrades were noted. [49] documented the sensitivity of oyster (Crassostrea gigas) and sea urchin (Paracentrotus lividus) embryos and larvae to $\mathrm{Cu}$, and reported the very high occurrence of abnormalities at concentrations of $150 \mu \mathrm{g} / \mathrm{l}$ and $100 \mu \mathrm{g} / \mathrm{l}$, respectively. In our experiments, the benthic foraminifera were not severely affected by $\mathrm{Cu}$ exposure. The concentrations used (60 to $2400 \mu \mathrm{g} / \mathrm{l}$ ) were much higher than those utilized (10 to $50 \mu \mathrm{g} / \mathrm{l})$ by [41] who nevertheless observed more severe effects than we did. A possible explanation may be the different approach used, as [41] exposed two species of Ammonia directly to $\mathrm{Cu}$-contamination. In our experiment, however, the benthic foraminifera were maintained in ambient sediments and the effect of $\mathrm{Cu}$-contamination might have been limited to the sediments themselves. Accordingly, very high concentrations of $\mathrm{Cu}(>900 \mathrm{ppm})$ in the sediments were utilized by [20] and only minor effects were reported. Moreover, concentrations higher than $2000 \mathrm{ppm}$ did not prevent the ability of foraminifera to colonize the substrates. According to [50], this largely supports the idea that it is not the total concentration of $\mathrm{Cu}$ (or any kind of trace element) within sediments that affects foraminifera, but the fraction of the element that is bioavailable. The present study can be regarded as complementary to long-term field studies and culture experiments, since the experimental period might have been too short to monitor a potential ecological succession of the assemblage. Unlike several previous investigations $[41,42,45,46]$, this study does not address the response of one species to one pollutant, but instead aims to document the response of benthic foraminifera at an assemblage level.

\section{Conclusion}

In general, controlled experiments, including mesocosms and laboratory cultures, are used to identify a potential specific cause-effect relationship that has been previously inferred in field studies. This study confirms that the use of this experimental approach is suitable for investigating the response of benthic foraminifera to stress, including pollution. Moreover, the application of mesocosms is an innovative tool to be placed alongside field studies and culture experiments. This study documents that $\mathrm{Cu}$ contamination has a detrimental effect on benthic foraminifera, including a reduction in density and species diversity, and higher levels of abnormalities.

\section{REFERENCES}

[1] J. W. Murray, "Ecology and Paleoecology of Benthic Foraminifera,” Longman, Harlow, 1991.
[2] E. Alve, "Benthic Foraminifera Response to Estuarine Pollution: A Review," Journal of Foraminiferal Research, Vol. 25, No. 3, 1995, pp. 190-203. doi:10.2113/gsjfr.25.3.190

[3] V. Yanko, A. J. Arnold and W. C. Parker, "Effects of Marine Pollution on Benthic Foraminifera," In: B. K. Sen Gupta, Ed., Modern Foraminifera, Kluwer Academic Publisher, Dordrecht, 1999, pp. 217-235.

[4] R. Coccioni, "Benthic Foraminifera as Bioindicators of Heavy Metal Pollution-A Case Study from the Goro Lagoon (Italy)," In: R. E. Martin, Ed., Environmental Micropaleontology: The Application of Microfossils to Environmental Geology, Kluwer Academic/Plenum Publishers, New York, 2000, pp. 71-103.

[5] E. Armynot du Châtelet and J.P. Debenay, "Anthropogenic Impact on the Western French Coast as Revealed by Foraminifera: A Review," Revue de Micropaléontologie, Vol. 53, No. 3, 2010, pp. 129-137. doi:10.1016/j.revmic.2009.11.002

[6] F. Frontalini and R. Coccioni, R., "Benthic Foraminifera as Bioindicators of Pollution: A Review of Italian Research over the Last Three Decades," Revue de Micropaléontologie, Vol. 54, No. 2, 2011, pp. 115-127. doi:10.1016/j.revmic.2011.03.001

[7] F. Frontalini, C. Buosi, S. Da Pelo, R. Coccioni, A. Cherchi and C. Bucci, "Benthic Foraminifera as Bio-Indicators of Trace Element Pollution in the Heavily Contaminated Santa Gilla Lagoon (Cagliari, Italy)," Marine Pollution Bulletin, Vol. 58, No. 6, 2009, pp. 858-877.

doi:10.1016/j.marpolbul.2009.01.015

[8] E. Geslin, J. P. Debenay and M. Lesourd, "Abnormal Wall Textures and Test Deformation in Ammonia (Hyaline Foraminifer)," Journal of Foraminiferal Research, Vol. 28, No. 2, 1998, pp. 148-156.

[9] J. W. Murray, "Ecology and Applications of Benthic Foraminifera", Cambridge University Press, Cambridge, 2006.

[10] R. Nigam, R. Saraswat and R. Panchang, "Application of Foraminifers in Ecotoxicology: Retrospect, Perspect and Prospect," Environmental International, Vol. 32, No. 2, 2006, pp. 273-283. doi:10.1016/j.envint.2005.08.024

[11] O. Gross, "Influence of Temperature, Oxygen and Food Availabilityon the Migrational Activity of Bathyal Benthic Foraminifera: Evidence of Microcosm Experiments," Hydrobiologia, Vol. 426, No. 1, 2000, pp. 123-137. doi:10.1023/A:1003930831220

[12] M. Gustafsson, I. Dahllof, H. Blanck, P. Hall, S. Molander and K. Nordberg, "Benthic Foraminiferal Tolerance to Tri-n-Butyltin (TBT) Pollution in an Experimental Mesocosm," Marine Pollution Bulletin, Vol. 40, No. 12, 2000, pp. 1072-1075. doi:10.1016/S0025-326X(00)00048-5

[13] P. Heinz, H. Kitazato, G. Schmiedl and C. Hemleben, "Response of Deep-Sea Benthic Foraminifera from the Mediterranean Sea to Simulated Phytoplankton Pulses under Laboratory Conditions," Journal of Foraminiferal Research, Vol. 31, No. 3, 2001, pp. 210-227. doi: $10.2113 / 31.3 .210$

[14] P. Heinz, C. Hemleben and H. Kitazato, "Time-Response 
of Cultured Deep-Sea Benthic Foraminifera to Different Algal Diets," Deep Sea Research I, Vol. 49, No. 3, 2002, pp. 517-537. doi:10.1016/S0967-0637(01)00070-X

[15] I. A. P. Duijnstee, S. R. Ernst and G. J. Van der Zwaan, "The Effect of Anoxia on the Vertical Migration of Benthic Foraminifera," Marine Ecology Progress Series, Vol. 246, 2003, pp. 85-94. doi:10.3354/meps246085

[16] S. R. Ernst, I. A. P. Duijnstee and G. J. Van der Zwaan, "The Dynamics of the Benthic Foraminiferal Microhabitat: Recovery after Experimental Disturbance," Marine Micropaleontology, Vol. 46, No. 3-4, 2002, pp. 343-361. doi:10.1016/S0377-8398(02)00080-4

[17] S. R. Ernst, R. Bours, I. A. P. Duijnstee and G. J. Van der Zwaan, "Experimental Effects of an Organic Matter Pulse and Oxygen Depletion on a Benthic Foraminiferal Shelf Community," Journal of Foraminiferal Research, Vol. 35, No. 3, 2005, pp. 177-197. doi:10.2113/35.3.177

[18] S. R. Ernst, J. Morvan, E. Geslin, A. Le Bihan and F. J. Jorissen, "Benthic Foraminiferal Response to Experimentally Induced Erika Oil Pollution," Marine Micropaleontology, Vol. 61, No. 1-3, 2006, pp. 76-93. doi:10.1016/j.marmicro.2006.05.005

[19] J. N. Topping, J. W. Murray and D. W. Pond, "Sewage Effects on the Food Sources and Diet of Benthic Foraminifera Living in Oxic Experiment: A Microcosm Experiment," Journal of Experimental Marine Biology and Ecology, Vol. 329, No. 2, 2006, pp. 239-250. doi:10.1016/j.jembe.2005.09.013

[20] E. Alve and F. Olsgard, "Benthic Foraminiferal Colonization in Experiments with Copper-Contaminated Sediments," Journal of Foraminiferal Research, Vol. 29, No. 3, 1999, pp. 186-195.

[21] M. J. Kennish, "Ecology of Estuaries: Anthropogenic Effects," CRC Press Inc., Boca Raton, 1992.

[22] M. C. Austen and P. J. Somerfield, "A Community Level Sediment Bioassay Applied to an Estuarine Heavy Metal Gradient," Marine Environmental Research, Vol. 43, No. 4, 1997, pp. 315-328. doi:10.1016/S0141-1136(96)00094-3

[23] G. W. Bryan and W. J. Langston, "Bioavailability, Accumulation and Effects of Heavy Metals in Sediments with Special Reference to United Kingdom Estuaries-A Review," Environmental Pollution, Vol. 76, No. 2, 1992, pp. 89-131. doi:10.1016/0269-7491(92)90099-V

[24] E. R. Long, D. D. MacDonald, S. L. Smith and F. D. Calder, "Incidence of Adverse Biological Effects within Ranges of Chemical Concentrations in Marine and Estuarine Sediments," Environmental Management, Vol. 19, No. 1, 1995, pp. 81-97. doi:10.1007/BF02472006

[25] F. Frontalini and R. Coccioni, "Benthic Foraminifera for Heavy Metal Pollution Monitoring: A Case Study from the Central Adriatic Sea Coast of Italy," Estuarine Coastal and Shelf Science, Vol. 76, No. 20, 2008, pp. 404-417. doi:10.1016/j.ecss.2007.07.024

[26] F. Frontalini, F. Semprucci, R. Coccioni, M. Balsamo, P. Bittoni and A. Covazzi-Harriage, "On the Quantitative Distribution and Community Structure of the Meio and Macrofaunal Communities in the Coastal Area of the Central Adriatic Sea (Italy)," Environmental Monitoring
Assessment, Vol. 180, No. 1-4, 2011, pp. 325-344. doi:10.1007/s10661-010-1791-y

[27] Activation Laboratories Ltd., Ontario, Canada, http://www.actlabs.com

[28] S. R. Ernst and B. van der Zwaan, "Effects of Experimentally Induced Raised Levels of Organic Flux and Oxygen Depletion on a Continental Slope Benthic Foraminiferal Community," Deep Sea Research I, Vol. 51, No. 11, 2004, pp. 1709-1739. doi:10.1016/j.dsr.2004.06.003

[29] W. R. Walton, "Techniques for Recognition of Living Foraminifera," Contribution of Cushman. Foundation Foraminiferal Research, Vol. 3, 1952, pp. 56-60.

[30] H. C. De Stigter, F. J. Jorissen and G. J. Van der Zwaan, "Bathymetric Distribution and Microhabitat Partitioning of live (Rose Bengal Stained) Benthic Foraminifera along a Shelf to Deep Sea Transect in the Southern Adriatic Sea," Journal of Foraminiferal Research, Vol. 28, No. 1, 1998, pp. 40-65.

[31] F. Cimerman and M. R. Langer, "Mediterranean Foraminifera," Slovenska Akademija Znanosti in Umetnosti, Ljubljana, 1991.

[32] A. R. Loeblich Jr. and H Tappan, "Foraminiferal Genera and Their Classification," Van Reinhold Company, New York, 1987.

[33] R. Coccioni, F. Frontalini, A. Marsili and D. Mana, "Benthic Foraminifera and Trace Element Distribution: A Case-Study from the Heavily Polluted Lagoon of Venice (Italy)," Marine Pollution Bulletin, Vol. 59, No. 8-12, 2009, pp. 257-267. doi:10.1016/i.marpolbul.2009.08.009

[34] G. A. Seiglie "Foraminifers of Guayanilla Bay and Their Use as Environmental Indicators," Revista Espanola de Micropaleontologia, Vol. 7, No. 3, 1975, pp. 453-487.

[35] F. J. Jorissen, "Benthic Foraminifera from the Adriatic Sea: Principles of Phenotypic Variation," Utrecht Micropaleontological Bulletin, Vol. 37, 1988, pp. 1-174.

[36] V. Stouff, E. Geslin, J. P. Debenay and M. Lesourd, "Origin of Morphological Abnormalities in Ammonia (Foraminifera): Studies in Laboratory and Natural Environments," Journal of Foraminiferal Research, Vol. 29, No. 2, 1999, 152-170.

[37] J. Morvan, J., V. Le Cadre, F. J. Jorissen and J. P. Debenay, "Foraminifera as Potential Bio-Indicators of the 'Erika' Oil Spill in the Bay of Bourgneuf: Field and Experimental Studies," Aquatic Living Resources, Vol. 17, No. 3, 2004, pp. 317-322. doi:10.1051/alr:2004034

[38] E. Armynot du Châtelet, J. P. Debenay and R. Soulard, "Foraminiferal Proxies for Pollution Monitoring in Moderately Polluted Harbours," Environmental Pollution, Vol. 127 , No. 1, 2004, pp. 27-40. doi:10.1016/S0269-7491(03)00256-2

[39] V. Yanko, J. Kronfeld and A. Flexer, "Response of Benthic Foraminifera to Various Pollution Sources: Implications for Pollution Monitoring," Journal of Foraminiferal Research, Vol. 24, No. 1, 1994, 1-17. doi:10.2113/gsjfr.24.1.1

[40] A. V. Fursenko, "Introduction to the Study of Foraminifera," in Russian, Nauka, Novosibirsk, 1978. 
[41] V. Le Cadre and J. P. Debenay, "Morphological and Cytological Responses of Ammonia (foraminifera) to Copper Contamination: Implication for the Use of Foraminifera as Bioindicators of Pollution," Environmental Pollution, Vol. 143, No. 2, 2006, pp. 304-317. doi:10.1016/j.envpol.2005.11.033

[42] A. R. Sharifi, I. W. Crondace and R. L. Austin, "Benthic Foraminiferids as Pollution Indicators in Southampton Water, Southern England, UK," Journal of Micropaleontology, Vol. 10, No. 1, 1991, pp. 109-113. doi:10.1144/jm.10.1.109

[43] D. Munsel, U. Kramar, D. Dissard, G. Nehrke, Z. Berner, J. Bijma, G.-J. Reichart and T. Neumann, "Heavy Metal Uptake in Foraminiferal Calcite: Results of Multi-Element Culture Experiments," Biogeosciences Discussion, Vol. 7, No. 1, 2010, pp. 953-977. doi:10.5194/bgd-7-953-2010

[44] L. J. de Nooijer, G. J. Reichart, A. Duenas-Bohòrquez, M. Wolthers, S. R., Ernst, P. R. D. Mason and G. J. van der Zwaan, "Copper Incorporation in Foraminiferal Calcite: Results from Culturing Experiments," Biogeosciences, Vol. 4, No. 4, 2007, pp. 493-504. doi:10.5194/bg-4-493-2007

[45] R. Saraswat, S. R. Kurtarkar, A. Mazumder and N. Nigam, "Foraminifers as Indicators of Marine Pollution: A Culture Experiment with Rosalina leei," Marine Pollution Bulletin, Vol. 48, No. 1-2, 2004, pp. 91-96. doi:10.1016/S0025-326X(03)00330-8
[46] N. Nigam, V. N. Linshy, S. R. Kurtarkar and R. Saraswat, "Effects of Sudden Stress due to Heavy Metal Mercury on Benthic Foraminifer Rosalina leei: Laboratory Culture Experiment," Marine Pollution Bulletin, Vol. 59, No. 812, 2009, pp. 362-368. doi:10.1016/j.marpolbul.2009.08.014

[47] B. J. McCloskey, "Foraminiferal Responses to Arsenic in a Shallow-Water Hydrothermal System in Papua New Guinea and in the Laboratory," Ph.D. Thesis, University of South Florida, Tampa, 2009.

[48] M. R. Lee and J. A. Correa, "An Assessment of the Impact of Copper Mine Tailings Disposal on Meiofaunal Assemblages Using Microcosm Bioassays," Marine Environmental Research, Vol. 64, No. 1, 2007, pp. 1-20. doi:10.1016/j.marenvres.2006.11.001

[49] E. His, I. Heyvang, O. Geffard and X. De Montaudouin, "A Comparison between Oyster (Crassostrea gigas) and Sea Urchin (Paracentrotus lividus) Larval Bioassays for Toxicological Studies," Water Research, Vol. 33, No. 7, 1999, pp. 1706-1718. doi:10.1016/S0043-1354(98)00381-9

[50] E. Alve, A. Lepland, J. Magnusson and K. Backer-Owe, "Monitoring Strategies for Re-Establishment of Ecological Reference Conditions: Possibilities and Limitations," Marine Pollution Bulletin, Vol. 59, No. 8-12, 2009, pp. 297-310. doi:10.1016/j.marpolbul.2009.08.011 